\title{
Simultaneous Determination of Thyroxine and Simplified Free Thyroxine Index by Thyopac-4 Kit, and Their Clinical Evaluation in Assessment of Thyroid Function
}

\section{Satoshi HAMADA, Tadako KOSAKA, Toru MORI, Yosuke TAKEDA, Katsuji IKEKUBO and Kanji TORIZUKA}

Radioisotope Research Genter, Kyoto University, Gentral Radioisotope Division, Kyoto University Hospital, and Department of Radiology, Kyoto University School of Medicine, Kyoto

A simplified method was devised for simultaneous determination of thyroxine (T4) and free T4 index (FT4I) by using a single kit of Thyopac-4. Firstly, T4 values of patient and pooled normal serum were determined according to the instruction. Thereafter, $5 \mu$ of the patient or pooled normal serum was added to each Thyopac-4 vial, and incubated for $60 \mathrm{~min}$. After settlement of granules, supernatants were removed for counting. FT4I was calculated by the following equation:

$$
\mathrm{Y}=\frac{\mathrm{T} 4 \mathrm{p}}{\mathrm{T} 4 \mathrm{n}} \div \frac{\mathrm{Fp}-\mathrm{Ep}}{\mathrm{Fn}-\mathrm{En}}
$$

where $\mathrm{E}$ and $\mathrm{F}$ were net counts in the supernatants before and after addition of serum, and suffices $\mathrm{p}$ and $\mathrm{n}$ indicate patient and pooled normal serum. For comparison, Tetrasorb and Triosorb tests were performed using the same samples, and free T4 indices were calculated according to Clark's, Tetrasorb $\times$ Triosorb/100, and our previously reported method, Tetrasorb $\times$ Triosorb $/ 100 \div(1-0.6 \times$ Triosorb $/ 100)$, which bore a straight-line relationship to measured free T4 (Hamada et al, J. Clin. Endrocrinol. Metab. 31: 166, 1970). Dual competitive protein binding analysis of T4, Thyopac ETR, was carried out by the method reported elsewhere: Fn/Fp (Hamada et al, J. Clin. Path. in press).

T4 values obtained by Thyopac-4 kits bore a linear relationship to but tended to be slightly higher than those by Tetrasorb kits, as expressed by a regression equation: $\mathrm{Y}=$ $0.99 \mathrm{x}+1.35$.

Values for Thyopac ETR were significantly increased and decreased in hyper-and hypothyroidisms, respectively, whilst they remained within the normal range in pregnancy and TBG deficiency, the results confirming our previous report.

A ratio of increased radioactivity after addition of patient or pooled normal serum, $(\mathrm{Fp}-\mathrm{Ep}) /(\mathrm{Fn}-\mathrm{En})$, was shown to have relationships reciprocal to T3 resin sponge uptake $(r=-0.71)$ and linear to the reciprocals of the latter $(r=+0.78)$. Therefore, it was possible to determine the present FT4I according to Clark's approximation to free T4.

The simplified FT4I values were $1.05 \pm 0.36$ (mean \pm SD) for normal, $3.46 \pm 1.25$ for hyperthyroid, $0.16 \pm 0.13$ for hypothyroid, and $0.95 \pm 0.29$ for pregnant subjects. Fur- 
ther, the present index was shown to bear almost linear relationships to both Clark's and our previously reported indices, correlation co-efficients of which were +0.92 and +0.88 , respectively.

It was concluded, therefore, that the present method was very useful as a routine test for assessment of thyroid status, because only $0.505 \mathrm{ml}$ was required to obtain the values for all the three indicators of thyroid function, namely, T4, FT4I and Thyopac ETR.

(See pp. 942 951) 


\title{
Thyopac-4 キットによる簡易な Free Thyroxine Index 測定法とその臨床的評価について
}

\author{
京大放射性同位元素総合センター \\ 浜田哲 \\ 京大病院中央放射線部 \\ 高坂唯子 \\ 京大医学部放射線学教室 \\ 森徹, 竹田洋祐 \\ 池 窪 勝 治, 鳥 塚 莞 爾
}

（昭和 49 年 2 月 6 日受付）

Thyopac-4 キットを用いて Thyroxine（T4）値を測定すると共に，同バイアルに少量の患者血清を 添加して簡易 Free T4 Index を測定した。本 Index は, 甲状腺機能克進症では有意の高值を示し, 機能低下症では有意の低值を示すのに対し, 妊娠及び TBG 欠損症では正常值を示し, 更に, Free T4 の実測值と直線関係をもつ我々の Free T4 Index とほぼ平行し，またClark の Free T4 Index と 直線関係にあつて, Free T4 濃度をよく反映した，本法の所要血清量は $0.5 \mathrm{ml}$ に過ざず，日常の甲状 腺機能検査法として有用と考元られた。

緒 言

血清中の遊離型 Thyroxine（Free T4）は，末梢細胞に直接移行してホルモン作用を呈すると共に，間脳 ・下垂体に作用してホルモンの分泌調節に関与し, 甲状腺機能状態の最も良い指標であるてとか認められて いる1). 最近 Triiodothyronine (T3) のホルモン作用における役割が再び重視されるに至つたが゚，甲状腺 機能の異常が T3 のみに帰せられる場合は一部に限られており ${ }^{334)}$ ，一般には T3 值は T4 值に平行し 586),

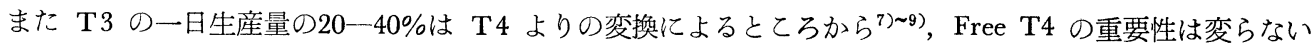

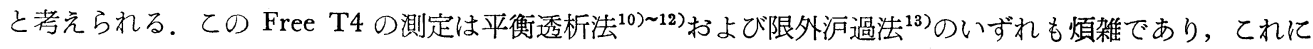
代るものとして， T4 值と血清 T4 結合グロブリン (TBG) 亿関する指標とから Free T4 濃度に平行す

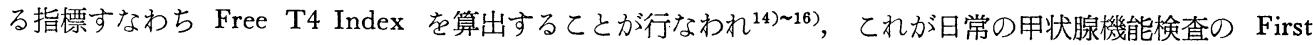
choice ${ }^{17)}$ であるととが報告されている.

これらの Free T4 Index の算出には 2 種類のキットによる測定が必要であるのに対し, 最近 T4 の Dual competitive Protein Binding Analysis が開発され，TBG の異常の有無に拘らず，一回の測定で甲状腺機

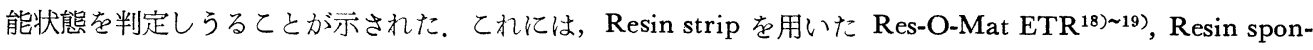

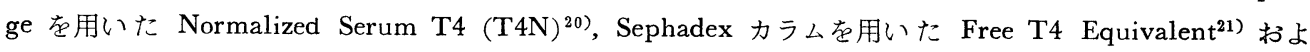
び Sephadex 顆粒を用いた Thyopac ETR ${ }^{22)}$ なぞがあり，いずれも日常の臨床検査法として有用であるて とが認められた。 また以上の変法として, 稻田ら ${ }^{23)}$ は Res-O-Mat T4 キットを用い, 我々 ${ }^{22}$ は Thyopac-4 キットを用いてT4值を先ず測定したのち，引続き Dual competitive Binding Analysis を行うととを報告 
した，ての場合に，TBG 欠損症または妊娠を始めとする TBG 増多症では, Dual competitive Binding Analysis が正常值を示すにも拘らず，T4 值は前者では低值また後者では高值を示し，両測定值の解離か ら TBG 異常を推定するてとが或程度可能であつた。

しかしながら以上の Dual competitive Binding Analysis の測定值はいずれも Free T4 值と必ずしも 平行せず，甲状腺機能充進症および低下症で頭打ち現象がみられてその重症度を正しく反映しない難点がみ られた，我々は先に発表した Thyopac ETR 法を改良し，Free T4 值にほほ平行する簡易な Free T4 Index 測定法を考案し，てれが甲状腺機能の診断に一層有用であるととを認めたので報告する.

\section{方法および検查対象}

検查対象は京大医学部附属病院第 2 内科・放射線科合同甲状腺外来を受診し，臨床所見，各種甲状腺機能 検查わよび針生検等により䛦断の確定した未治療甲状腺機能六進症 26 例，未治療機能低下症 14 例，先天性 TBG 欠損症 1 例および大阪北野病院入院中の正常妊娠後期婦人（29-40週）15例，ネフローゼ症候群 1 例 並びに健康者20例の合計77例であつた。

Triosorb および Tetrasorb は所定の方法に従つて測定され, 両者の積即ち Clark の Free T4 Index ${ }^{15}$ が算出された.

また，Free T4 の実測值と直線関係を示す著書らの Free T4 Index が次式より算出され ${ }^{16)}$,

Free T4 Index $=\frac{\text { Tetrasorb } \times \text { Triosorb } / 100}{1-0.6 \times \text { Triosorb } / 100} \cdots(1)$

他の測定值と比較された.

Thyopac-4 キットによる T4 值および Thyopac ETR 值並びに Free T4 Index の簡易測定法

（1）被検血清 $0.5 \mathrm{ml}$ とエタノール $1.0 \mathrm{ml}$ とを抽出用バイアルに入れて振晹する． 0 および $18 \mu \mathrm{g}$ スタ ンダード並びに正常プール血清を duplicate で同様に行う.

(2) Rotator で室温にて 2 分間混和する.

(3) 2000 回転で 5 分間遠沈する.

(4) 上清 $0.5 \mathrm{ml}$ をとり, Thyopac-4 バイアルに入れて蓋をする.

(5) Rotator で室温にて30分間混和する.

(6) 2 分間静置して顆粒を沈澱させ，上清 $1.0 \mathrm{ml}$ をとつて測定用試験管に移し， ${ }^{125} \mathrm{I}$ を測定する。 Net Count を $\mathrm{E}$ とする. $10^{7} / \mathrm{E}=1 / \mathrm{C}$ を計算し，スタンダード曲線より $\mathrm{T} 4$ 量を求める.

（7）先の Thyopac-4 バイアルにそれぞれ原血清 $5 \mu \mathrm{l}$ （または20倍稀釈血清 $0.1 \mathrm{ml}$ ）を加える. 正常プー ル血清についても同様に行なう。

(8) Rotator で室温にて60分間（30分間でも可）混和する.

(9) 2 分間静置して, 顆粒を沈澱させ, 上清 $1.0 \mathrm{ml}$ をとつて測定用試験管に移し， ${ }^{125} \mathrm{I}$ を測定する. Net Count をFとする.

Thyopac ETR $=\frac{\text { 正常プール血清のカウント }(\mathrm{Fn})}{\text { 患者血清のカウント }(\mathrm{Fp})}$

Thyopac 4 キットによる Free T4 Index（簡易 Free T4 Index $)=\frac{\mathrm{T} 4 \mathrm{p}}{\mathrm{Fp}-\mathrm{Ep}_{\mathrm{p}}} \div \frac{\mathrm{T} 4 \mathrm{n}}{\mathrm{Fn}-\mathrm{En}} \cdots(3)$ $\mathrm{n}:$ 正常プール血清

$\mathrm{p}$ : 患者血清

成績

各種の甲状腺疾患および TBG 異常を伴つた疾患についてえられた成績を要約して Table 1 亿示す。

Thyopac-4 キットによる T4 值 (Thyopac-4 值) は, 正常者では $8.6 \pm 2.2 \mu \mathrm{g} / 100 \mathrm{ml}$ (平均值士標準偏 差, 以下同じ) で, 甲状腺機能え進症および妊娠では有意の高值を示し, 機能低下症では有意の低值を示し 

価について（浜田，5名）

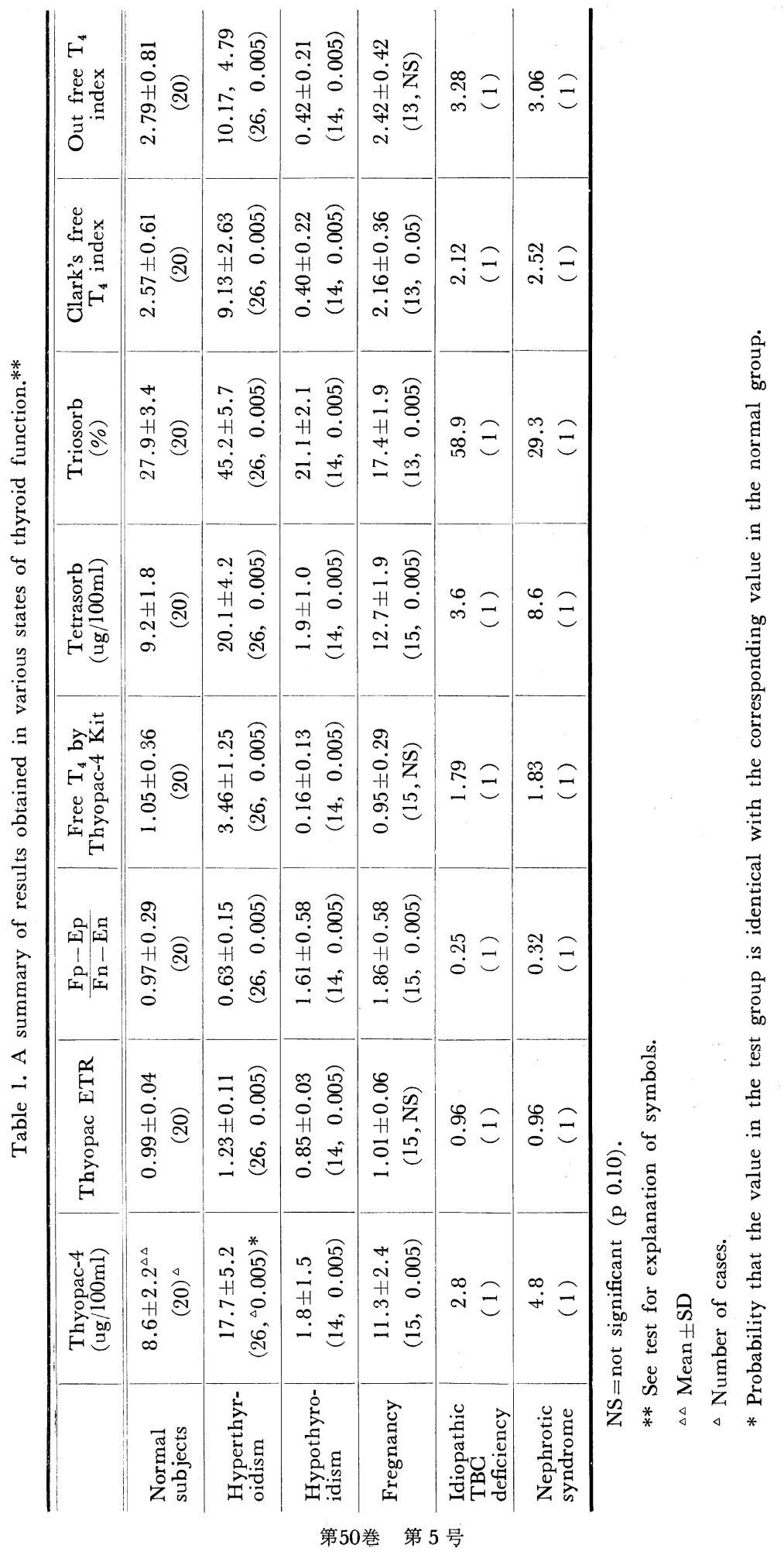


Fig. 1. Relation between T4 values by Thyopac-4 and Tetrasorb kits.

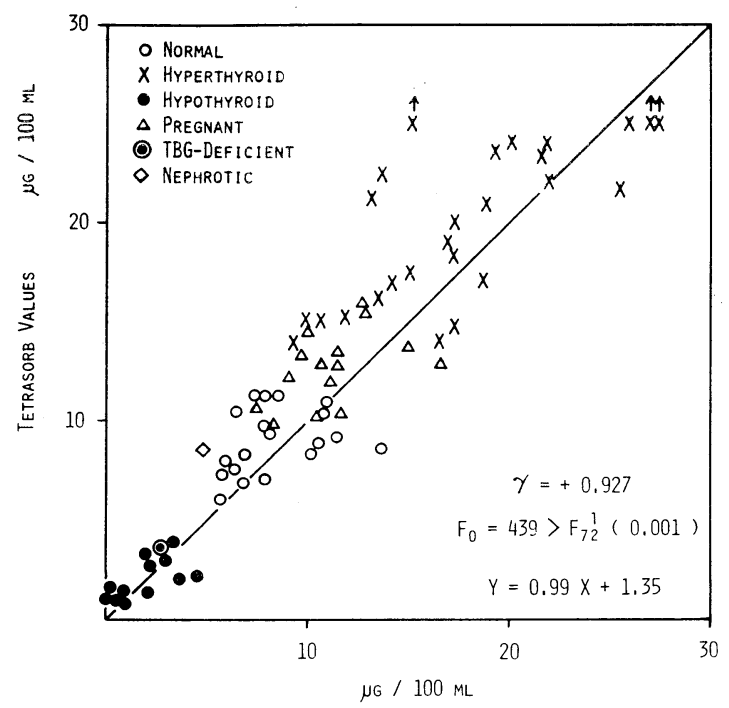

ThYOPAC- 4 VALUeS

Fig. 2. Thyopac ETR values in various states of thyroid function. Closed circles represent the mean and the vartical lines, one standard deviation.

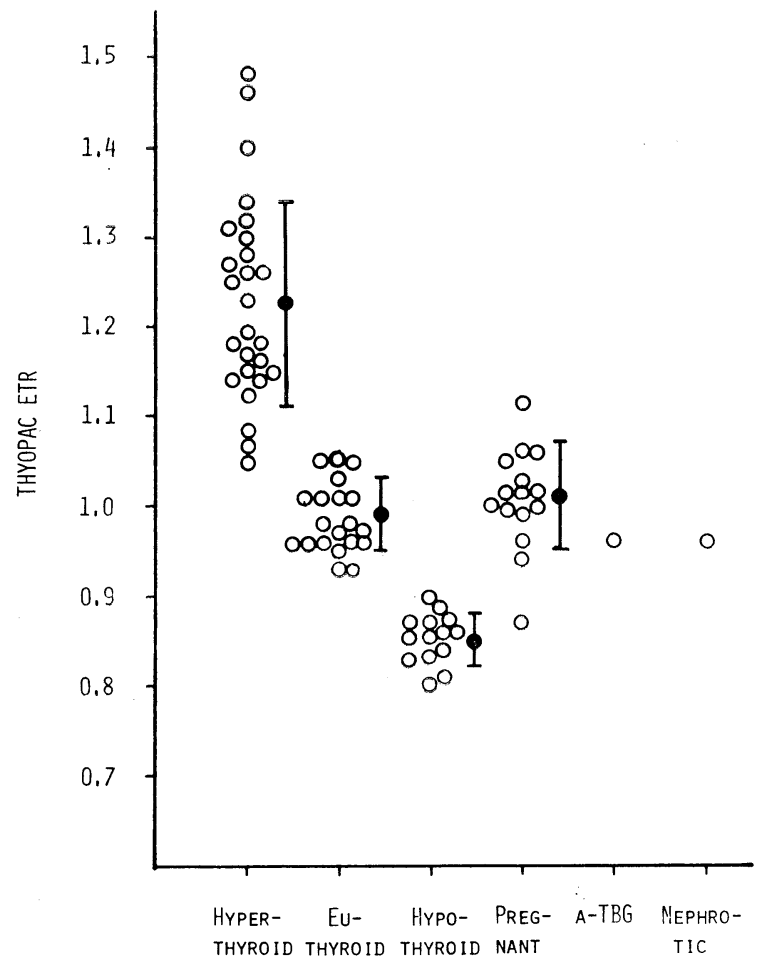

第 50 巻 第 5 号 
Fig. 3. Relation between Thyopac ETR values and our Free T4 Index which bore a straight-line relationship to measured free T4. A regression equation obtained was $\mathrm{Y}=23.5 \mathrm{X}^{2}-24.9 \mathrm{X}+4.5$.

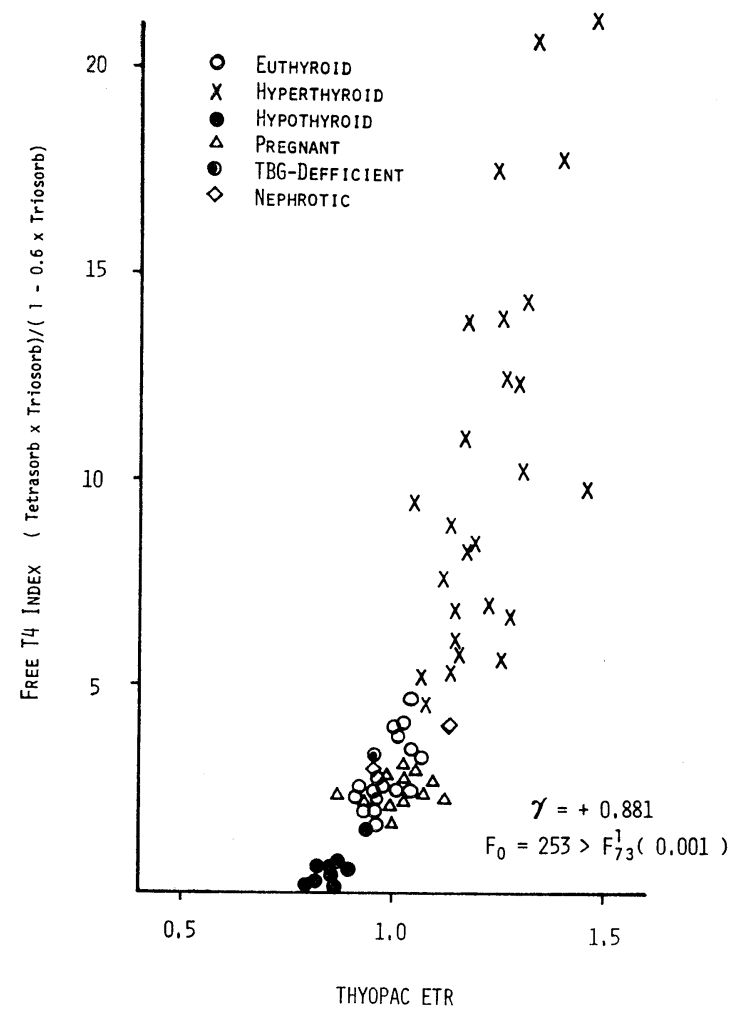

Fig. 4. Relation between $\mathrm{T} 3$ resin sponge uptake and ratio of increased radioactivity after addition of patient and pooled normal sernm.

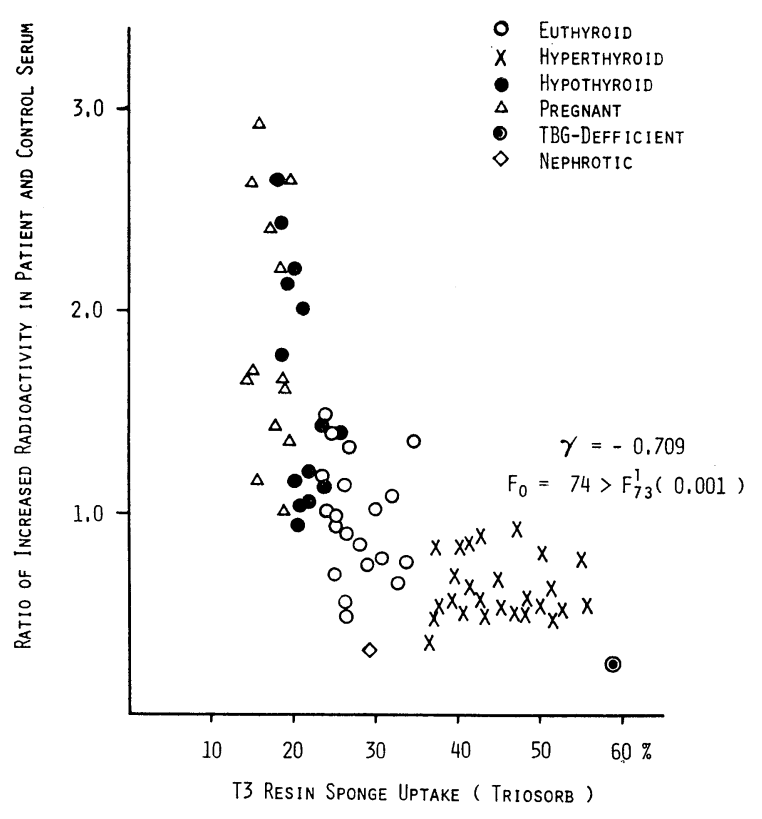

第 50 巻 第 5 号 
Fig. 5. Relation between reciprocals of $\mathrm{T} 3$ resin sponge uptake and ratio of increased radioaciivity after addition of patient and pooled normal serum.

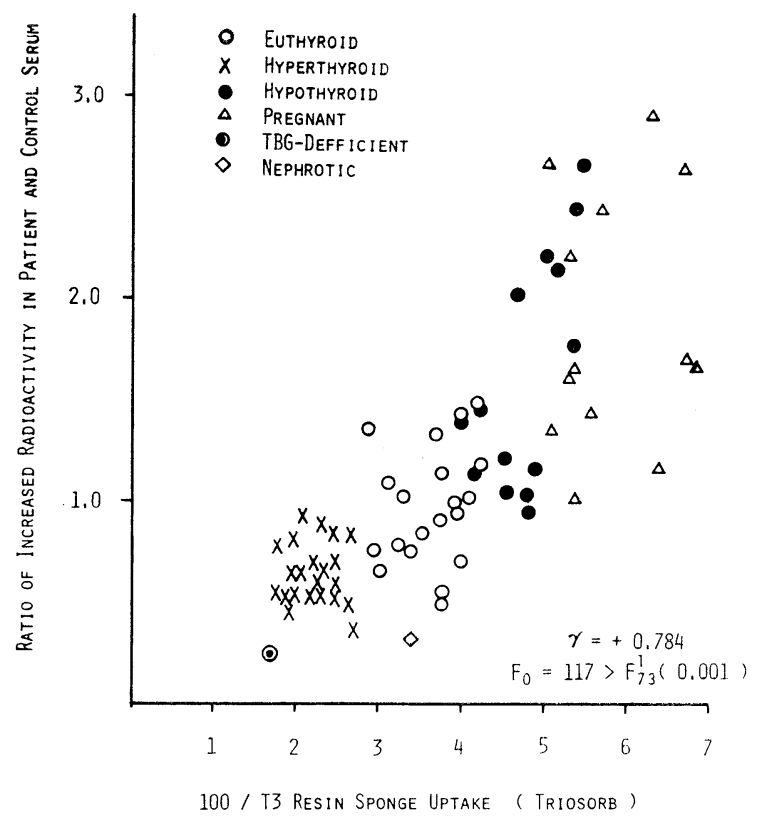

Fig. 6. Ratio of increased radioactivity after addition of patient and pooled normal serum in various states of thyroid function.

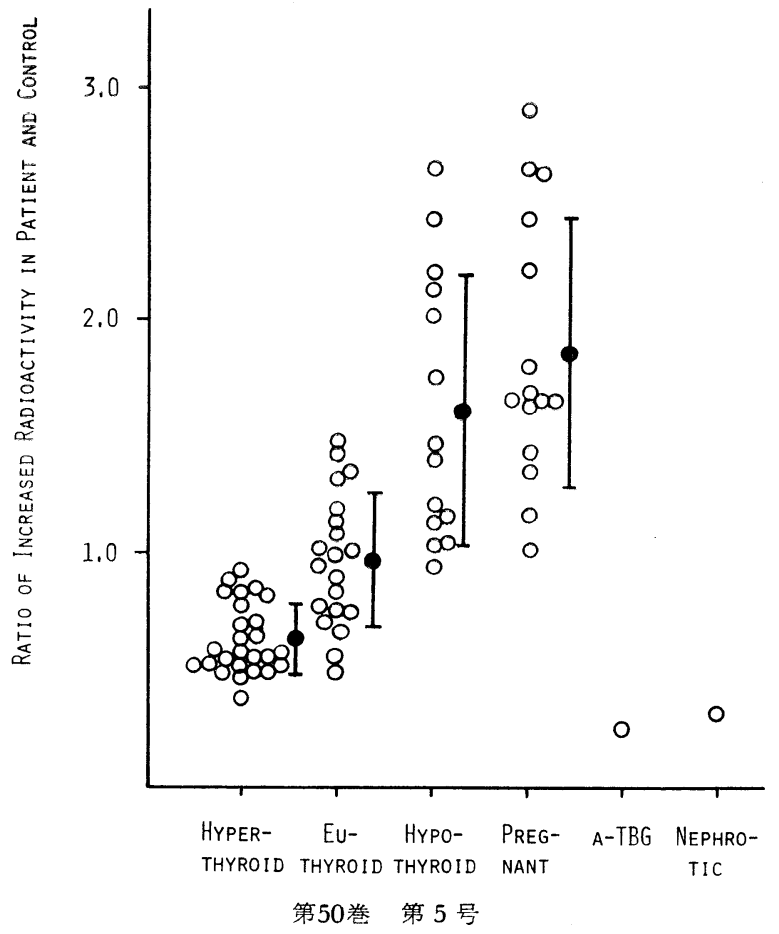



洒について（浜田，5名）

Fig. 7. Free T4 Index by Thyopac-4 kit in various states of thyroid function.

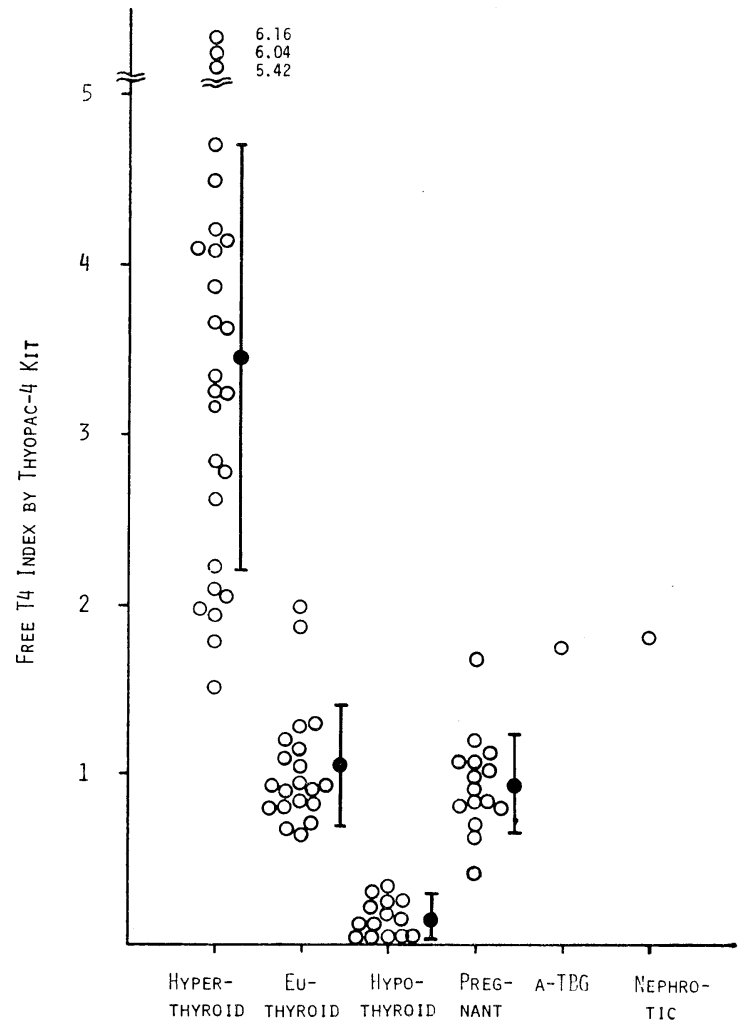

て，Tetrasorb による T4 值（Tetrasorb 值）と同様の成績であつた。しかし Fig.1 に示すように， Thyopac-4 值は Tetrasorb 值に比べて全体的に稍低い傾向を示し, 両者の相関は相関係数 +0.93 で, $\mathrm{Y}=$ $0.99 \mathrm{X}+1.35$ なる回帰直線式で示された.

Thyopac ETR 值は, Fig. 2 に示すように甲状腺機能充進症では有意の高值，また機能低下症では有意の 低值を示して正常群との間に重り合いは少なく，乙れに対し妊娠および TBG 欠損症では，T4 值の異常に もかかわらず正常値を示した，乙れらの成績は，著者らの先の報告と一致した ${ }^{22)}$.

Thyopac ETR 值と Free T4 との関係を，Free T4 の実測值と直線関係にある著者らの Free T4 Index を用いて Fig. 3 に示す. 両者間に相関係数 +0.88 有意の正相関が認められたが，その関係は非直線的で, $\mathrm{Y}=23.5 \mathrm{X}^{2}-24.9 \mathrm{X}+4.5$ 上いう回帰曲線式で表わされた.

一般に Free T4 Index を算出するためには，T4 值と共に TBG に関する指標例えば Triosorb 值が必 要である．しかし，もし原血清添加後の上清中の ${ }^{125} \mathrm{I}$ の増加量（F-E）が，その血清中に含まれる TBG 量と定量的関係を有するならば，乙れを TBG の指標として Free T4 Index を算出することが可能である. 患者血清添加時の増加量と正常プール血清添加時の増加量の比 : (Fp-Ep)/(Fn-En) と Triosorb 值との 間には，Fig. 4 に示すような有意の逆相関（相関係数，一0.71）が認められ，ほぼ双曲線上に分布した。従 つて Triosorb 值の逆数との関係をみると, Fig. 5 に示すように有意の正相関（相関係数, +0.78）が認め られ，ほぼ直線上に分布して，Y=0.35X-0.21なる回帰直線式がえられた．更に，本増加率は，Fig. 6 に 示すように, TBG 増加を来すととか知られている甲状腺機能低下症および妊娠では有意に増加し，逆に TBG 減少を来すととが知られている機能九進症および TBG 久損症では有意に減少した。 以上の成績は, 
日 本 内分泌学 会 雑 誌

Fig. 8. Relation between Free T4 Index by Thyopac-4 kit and Glark's Free T4 Index.

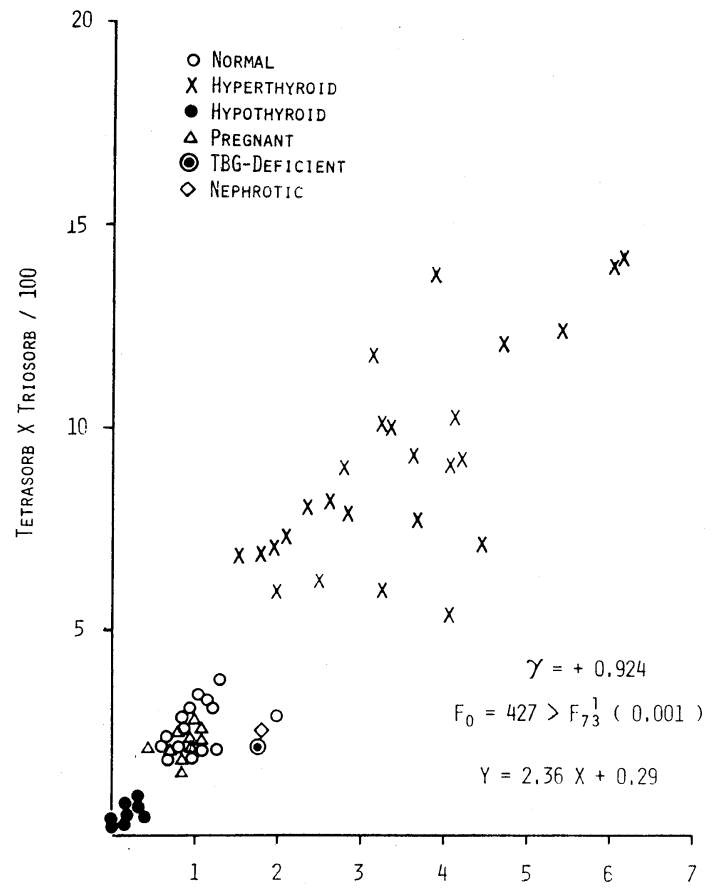

Free T4 Index by Thyopac-4 Kit

Fig. 9. Relation between Free T4 Index by Thyopac-4 kit and our Free T4 Index.

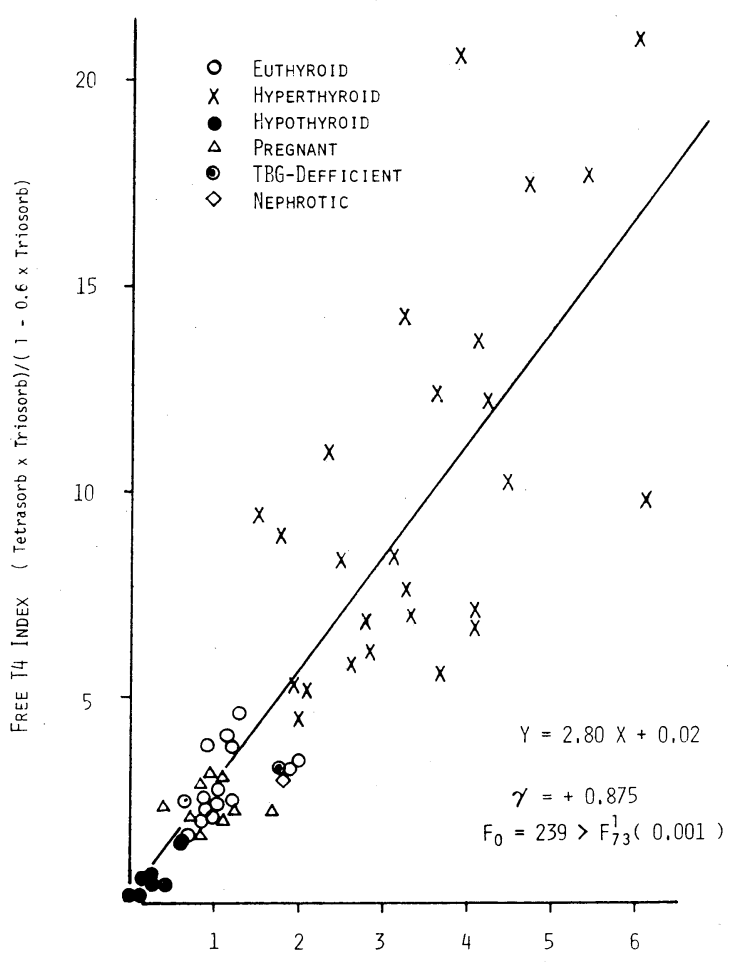

Free T4 Index by Thyopac-4 KIT

第 50 巻 第 5 号 
本増加率が血清中に含有される TBG 量に比例関係を有し, TBG の近似的指標として使用されうるととを 示すものである．従つて本増加率を用い， Glark らに準じて式(3)より Free T4 Index を算出した。

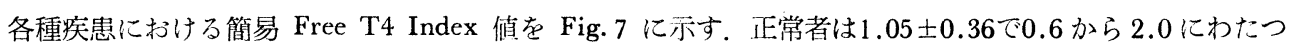
て分布し, 甲状腺機能充進症は $3.46 \pm 1.25$, 機能低下症は $0.16 \pm 0.13$ でいずれも正常者と有意に異なる值を 示した。乙れに対し妊娠は $0.95 \pm 0.29$ で正常値を示し, TBG 欠損症も正常域に分布した。

本 Index と Clark の Index との関係は, Fig. 8 亿示すようにほとんど直線的で, 有意の正相関（相関 係数，+0.92）が認められ，また著者らの Free T4 Index との関係も，Fig. 9 亿示すように有意の正相関 （相関係数，＋0.88）が認められて，本 IndexはFree T4 濃度にほぼ平行するてとが示された。

\section{考按}

甲状腺機能検查の First choice は Free T4 Index といわれ ${ }^{17)}$ ，少量の血清でこれを簡易に測定するの が，日常の甲状腺機能検查法の一つの方向と考元られる。本法は Thyopac- 4 キットのみを使用し, $0.5 \mathrm{ml}$ の血清で T4 值と共に Free T4 Index を容易に測定することができ，ての目的に合致するものといえる。

我々が先に報告した Thyopac ETR 法22) は, 他の種類の Dual Competitive Binding Analysis ${ }^{18) ~ 21) 23) ~}$ と同様に, Free T4 值が正常であるか否かの判定に有用であるが, Fig. 3 に示したように Free T4 濃度と 直線関係を示さない. 例杂ば Thyopac ETR 值は, 重症の甲状腺機能立進症でも 1.5 を越えるととなく, また重篤な機能低下症でも0.75を下らない，従つて本值はFree T4 濃度を正しく反映せず，てれにより重 症度を判定するにはての点に注意が必要である。

これに対し簡易 Free T4 Index では，TBG 欠損症で正常高值を示す傾向にあるが，甲状腺機能六進症 あるいは低下症と正常者および妊娠との間の重り合いは少なく, 更に, Free T4 の実測值と直線関係を示す 著者らの Free T4 Index とほほ平行し，またClark の Index とほとんど平行して，本 Index が Free T4 をより正しく反映するととが示された.

Free T4 と TBG との関係は次式によつて表わされる11.

[Free T4] $=\frac{[\text { TBG-Bound T4] }}{\text { K [Free TBG] } \cdots(4)}$

Clark $^{15)}$ らは Free TBG 濃度と逆数関係にある Triosorb と， TBG 結合 T4 量の代りに PBI（または T4）を用い，両者の積を Free T4 Index としたが，本法では，T4 值と，Triosorb 值と逆数関係にある 血清添加後の ${ }^{125} \mathrm{I}$-T4 の増加率との商を Free T4 Index としている. したがつて本 Index は原理的には Clark のIndex と同列のものであり, 後者との直線関係はてれを裏ずけるものである.

また本 Index は，Clark のIndex と同様に，式(4)の TBG 結合 T4 量の代りに T4 值を用いている. しかし TBG の最大結合能は小さく，また甲状腺機能克進症では更に減少するために，T4 が増加した場合 に TBG に結合する T4 量はプラトーに近ずき， T4 值と平行しない. このため本 Index も, Clark の Index と同様に, Free T4 濃度と直線的関係を示さないと考えられる. 著者らは, T4 と 3 種類の血清 $\mathrm{T} 4$ 結合蛋白との結合平衡に関する一般式(5) ${ }^{1}$ から, 式(1)に示した Free T4 Index

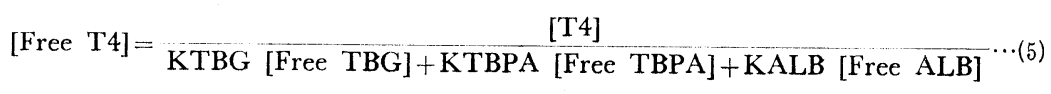
を算出し，乙れが夷測䛧と直線関係にあることを示した ${ }^{16)}$. Fig. 9 亿示したように，簡易 Free T4 Index が先の著者らのIndex と平行関係にはあるが直線性に稍众けるのは, 以上の事类によると考学られる.

しかしながら本 Index は, 日常の臨床検查法として Free T4 濃度の指標として十分使用しうるもので あり，また同時に T4 值も測定しえて, 甲状腺機能状態の診断に極めて有用であると結論された。

本研究飞御協力頂いた大阪北野病院植手鉄男博士および安藤啺哉博士並びに京大中央放射線部向井孝夫氏 に深謝致します。

本論文の要旨は第46回日本内分泌学会総会（昭和48年 4 月 9 〜11日, 京都）において発表した。 


\section{文献}

1) Robbins, J. and J.E. Rall : Physiol. Revs. $40: 415$ (1960).

2) Sterling, K. : Recent progr Hormone Res. 26 : 249 (1970).

3) Sterling, K., S. Refetoff, and H.A. Selenkow : J. Amer. Med. Assn. 213 : 571 (1970).

4) Hollander, C.S., T. Mitsuma, N. Nihei et al. : Lancet 1:609 (1972).

5) Larsen, P.R. : J. Glin. Invest. $51: 1939$ (1972).

6) Hesch, R.-D. and D. Evered : Brit Med. J. $1: 645$ (1973). 7) Braverman, L.E., S.H. Ingbar and K. Sterling : J. Glin. Invest. $49: 855$ (1970). 8) Schwarz, H.L., M.I. Surks, and J.H. Oppenheimer : J. Clin. Invest. 50 : 1124 (1971). 9) Pittman, C.S., J.B. Chambers, Jr., and V.H. Read : J. Clin. Invest. 50 : 1187 : (1971). 10) Oppenheimer, J.H., R. Squef, M.I. Surks, and H. Hauer : J. Clin. Invest. $42: 1769$ (1963).

11) Ingbar, S.H., L.H. Braverman, N.A. Dawber, and G.Y. Lee : J. Glin. Invest. 44 : 1679 (1965). 12) Sterling, K., and M.A. Brenner : J. Glin. Invest. $45: 153$ (1966).

13) Schussler, G.C., and

J.E. Plager : J. Glin. Endocrinol. Metab. $27: 242$ (1967).

Gartside, and A.W.G. Goolden : Clin. Sci. 23 : 525 (1962).

Clin. Endocrinol. Metab. 25 : 39 (1965). Torizuka : J. Glin. Endocrinol. Metab. 31 : 166 (1970). $\quad$ 17) Howorth, P.J.N., and R.L. Ward : J. Glin. Path. 25 : 259 (1972). 18) Mincey, E.K., S.C. Thorson, J.L. Brown, R.T. Morrison and H.W. McIntosh : J. Nucl. Med. $13: 165$ (1971). 19) 森 徹, 高坂唯子, 浜田 哲, 竹田 洋祐, 池窪勝治, 鳥塚莞爾：日本内分泌誌, $48: 685$, (1972). $\quad 20)$ Ashkar, S., and A.A. Bezjian : J. Amer. Med. Assn. 221 : 1483 (1972). $\quad$ 21) Abreau, G.M., F. Azizi, A.G.Vegenakis, S.H. Ingbar, and L.E. Braverman : J. Nucl. Med. $14: 159$ (1973). 22) 浜田 哲, 高坂唯子, 森 徹, 竹田洋祐, 池窪勝治, 鳥塚莞爾, 植手鉄男 : 核医学, $11: 15$, (1974). 23）稲田満夫, 岡部純一, 